\title{
Regulating Risks after ATA
}

\section{Citation}

Cass R. Sunstein, Regulating Risks after ATA (John M. Olin Program in L. \& Econ. Working Paper No. 127, 20011.

\section{Published Version}

http://chicagounbound.uchicago.edu/law_and_economics/416/

\section{Permanent link}

http://nrs.harvard.edu/urn-3:HUL.InstRepos:13030954

\section{Terms of Use}

This article was downloaded from Harvard University's DASH repository, and is made available under the terms and conditions applicable to Other Posted Material, as set forth at http:// nrs.harvard.edu/urn-3:HUL.InstRepos:dash.current.terms-of-use\#LAA

\section{Share Your Story}

The Harvard community has made this article openly available.

Please share how this access benefits you. Submit a story.

\section{Accessibility}




\section{University of Chicago Law School Chicago Unbound}

Coase-Sandor Working Paper Series in Law and

Economics

Coase-Sandor Institute for Law and Economics

2001

\section{Regulating Risks after ATA}

Cass R. Sunstein

Follow this and additional works at: http://chicagounbound.uchicago.edu/law_and_economics Part of the Law Commons

\section{Recommended Citation}

Cass R. Sunstein, "Regulating Risks after ATA" (John M. Olin Program in Law and Economics Working Paper No. 127, 2001).

This Working Paper is brought to you for free and open access by the Coase-Sandor Institute for Law and Economics at Chicago Unbound. It has been accepted for inclusion in Coase-Sandor Working Paper Series in Law and Economics by an authorized administrator of Chicago Unbound. For more information, please contact unbound@law.uchicago.edu. 


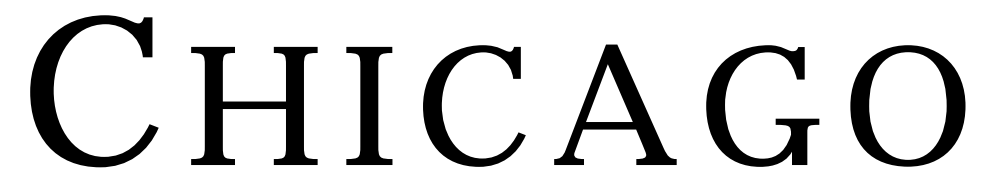

John M. Olin LAW \& ECONOMICS WORKING PAPER No. 127

(2D SERIES)

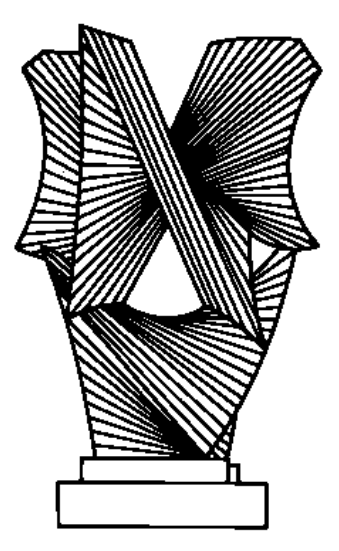

\title{
REgUlATING RISKS AFTER ATA
}

\author{
Cass R. Sunstein \\ THE LAW SCHOOL \\ THE UNIVERSITY OF CHICAGO
}

This paper can be downloaded without charge at:

The Chicago Working Paper Series Index:

http:/www.law.uchicago.edu/Lawecon/index.html

The Social Science Research Network Electronic Paper Collection: http://papers.ssrn.com/paper.taf?abstract_id=274189 
Preliminary draft 6/14/01

All rights reserved

\title{
Regulating Risks After ATA
}

\author{
Cass R. Sunstein ${ }^{*}$
}

\begin{abstract}
Whitman v. American Trucking Association was one of the most eagerly awaited regulatory decisions in many years. But the Court's understated, steady, lawyerly opinion was a bit of an anticlimax, representing a return to normalcy and leaving many open questions. The Court was correct to say that the relevant provision of the Clean Air Act forbids consideration of cost; it was also correct to refuse to invoke the nondelegation doctrine. Importantly, the Court left in place a set of important lower court decisions, allowing agencies to consider costs unless Congress expressly concludes otherwise. The Court also raised some new questions about the constitutional status of the Occupational Safety and Health Act. Perhaps most important, the Court has not ruled out nonconstitutional challenges to the particulates and ozone standards, or to ambient air quality standards generally. In suggesting that some of those challenges should succeed, especially against the new ozone regulation, this essay urges that Justice Breyer's concurring opinion in the case may well be the most influential in the future, because it fits most comfortably with other trends in the law of risk regulation, signaling the emergence of a kind of "cost-benefit state."
\end{abstract}

The last two decades have seen recurring conflicts between two strands in the law of risk regulation. The first strand, captured in what we might call "1970s environmentalism," places a high premium on immediate responses to evident hazards; rejects claims for quantification of likely benefits; and avoids or downplays consideration of cost. These tendencies play a role in prominent legislation $^{1}$ and also in the courts. ${ }^{2}$ The second strand, captured in what we

\footnotetext{
* Karl N. Llewellyn Distinguished Service Professor of Jurisprudence, University of Chicago, Law School and Department of Political Science. I am grateful to Richard A. Posner and Adrian Vermeule for helpful comments on a previous draft.

${ }^{1}$ See, e.g., 42 USC 7409(a), as interpreted in Whitman v. American Trucking Associations, 121 S.Ct. 903 (2001).

2 See Lead Industries Association v. EPA, 647 F.2d 1130 (DC Cir 1980); Ethyl Corp. v. EPA, 541 F.2d 1 (DC Cir 1976)..
} 
might call "the cost-benefit revolution," urges a highly quantitative approach to risk control, based on careful specification of both costs and benefits, and on close attention to relevant tradeoffs, including the risks sometimes introduced by regulation. These tendencies can be seen in prominent executive orders, ${ }^{3}$ in legislation, ${ }^{4}$ and in courts as well. ${ }^{5}$

Some of the most noteworthy conflicts between the two strands have involved efforts by courts to authorize agencies to make cost-benefit comparisons under statutes not explicitly calling for those comparisons. ${ }^{6}$ Recent presidents and courts have gone so far as to create a series of "cost-benefit default rules," allowing agencies to disregard trivial risks, requiring agencies to show significant benefits from regulation, allowing agencies to consider the substitute risks introduced by regulation, and authorizing agencies to take costs into account when statutes are not explicit on the point. ${ }^{7}$

Within the judiciary, the recent conflicts have pressed two questions in particular: When must agencies, including the Environmental Protection Agency (EPA), consider costs? ${ }^{8}$ When, if ever, will Congress be required to legislate with particularity? ${ }^{9}$ The latter question has not often thought to be especially interesting, because courts have not invoked the nondelegation doctrine to invalidate a federal statute since $1935 .{ }^{10}$ But a number of commentators have suggested that it is past time to revive the doctrine, partly in order to ensure legislative attention to tradeoffs rather than pleasant homilies. ${ }^{11}$ And in the last decade or so, some courts, concerned about the grant of open-ended discretion to the executive, have shown an unmistakable interest in doing exactly that. ${ }^{12}$

\footnotetext{
${ }^{3}$ See, e.g., Executive Order 12291, 46 Fed. Reg. 13193 (1980); Executive Order 12498, 50 Fed. Reg. 1036 (1985); Executive Order 12866, 58 Fed. Reg. 51735 (1993).

${ }^{4}$ See, e.g., 42 USC $300 f$ et seq. (Safe Drinking Water Act).

${ }^{5}$ See Corrosion Proof Fittings v. EPA, 947 F2d 1201 (5 $5^{\text {th }}$ Cir 1991).

${ }^{6}$ See State of Michigan v. EPA, 213 F3d 663, 678-79 (DC Cir 2000).

7 See Cass R. Sunstein, Cost-Benefit Default Rules, Mich :L Rev (forthcoming 2001).

8 See, e.g., NRDC v. EPA, 824 F.2d 1146, 1154-1166 (DC Cir 1987); George Warren Corp. V. EPA 159 F3d 616, 623-24 (DC Cir 1998).

9 See, e.g., National Lime Association v. EPA, 233 F3d 625 (DC Cir 2000).

10 Panama Refining Co. v. Ryan, 293 US 388 (1935); Schechter Poultry Corp. v. US, 295 US 495 (1935).

${ }^{11}$ See David Schoenbrod, Power Without Responsibility (1992); John Hart Ely, Democracy and Distrust (1981).

12 See American Trucking Assn. v. EPA, 175 F.3d 1027 (DC Cir 1999), reversed in part sub nom. Whitman v. EPA, 121 S. Ct. 903 (2001); International Union, UAW v. OSHA, 938 F.2d 1310 (DC Cir 1991); South Dakota v. Department of Interior, 69 F.2d 878 ( $8^{\text {th }}$ Cir 1995); Massieu v. Reno, 915 F Supp 681 (DNY 1996).
} 
Because it promised to help answer both of these two questions, Whitman v. American Trucking Association ${ }^{13}$ was the most eagerly anticipated case in administrative law in many years. In some circles, a dramatic decision was anticipated, raising the possibility of significant new directions in the law of environmental protection and risk regulation. On the central issues, however, the Court's unanimous, steady, lawyerly opinion amounted to a return to normalcy - and to an understated but unmistakable rebuke to some attempted innovations on the part of the court of appeals for the District of Columbia Circuit. In its principal ruling, the Supreme Court reaffirmed long-settled law to the effect that in setting national ambient air quality standards, the EPA is not permitted to consider costs. ${ }^{14}$ The Court also rejected a constitutional attack on the Clean Air Act, reestablishing long-settled law allowing Congress to delegate broad discretionary authority to regulatory agencies. ${ }^{15}$ And through this return to normalcy, the current Court treated the court of appeals for the District of Columbia in the same way that the 1970s Supreme Court treated that very court of appeals - attacking new judicial innovations and calling for at least a form of "hands off."16

The Court ruled quite broadly on both of the key issues, but it also reasoned in an extremely unambitious way, saying invoking statutory language and precedent while saying little about the topic of risk regulation and offering astonishingly little in the way of theoretical ground for its reluctance to invoke the nondelegation doctrine. We know that the Court is not much interested in reviving that doctrine; but we do not know why it lacks that interest. If we consider the importance of the case, the opinion seems a bit of an anticlimax, potentially even a judicial return to 1970s environmentalism. But two more interesting sets of issues lie beneath the dry surface. The first involves the state of the nondelegation doctrine. To be sure, the Court has signaled its lack of enthusiasm for the doctrine - indeed, it has given its clearest signal yet on that

13121 S. Ct. 903 (2001).

${ }^{14}$ For the initial part of the long settlement, see Lead Industries Association v. EPA, 647 F.2d 1130 (DC Cir 1980).

${ }^{15}$ See, e.g., Touby v. United States, 500 U.S. 160 (1991).

16 The leading case here is Vermont Yankee Nuclear Power Corp. v. NRDC, 435 US 519 (1978). See Antonin Scalia, Vermont Yankee, The Supreme Court, and the DC Circuit, 1978 Supreme Court Review 345. Professor Scalia's general (not unqualified) approval of the Supreme Court's rejection of policy initiatives by the D.C. Circuit finds a kind of echo in his majority opinion in ATA. 
point. At the same time, the Court's rejection of the approach of the court of appeals produces new questions about the nondelegation doctrine in some important domains of risk regulation, above all involving the Occupational Safety and Health Act (OSHA). As we shall see, ATA raises anew a serious constitutional question about a key provision of OSHA.

The second, and more pressing, set of issues stems from the Court's remarkably thin and unhelpful discussion of the meaning of the Clean Air Act (CAA). As we shall see, the same concerns that led the court of appeals to invoke the nondelegation doctrine might well reemerge on remand in ATA-and in many other contexts involving risk regulation. Above all, the court of appeals sought to require the EPA to attempt to quantify the risks that it was seeking to control, so as to ensure that the agency was attacking large problems rather than small ones. ${ }^{17}$ After ATA, this goal might be achieved through other, more modest routes, not involving the Constitution at all. While the ATA Court spoke largely in the terms of 1970s environmentalism, it did so in the context of an Article I challenge and a highly adventurous effort to inject cost considerations into an apparently cost-blind statutory provision. As I will urge, the decision should not be seen as an attack on more modest judicial innovations, nonconstitutional in nature, that attempt to increase the sense and rationality of risk regulation.

In this Article, I suggest reasons to approve of the principal holdings in $A T A$, arguing that the Court properly interpreted the key statutory provisions and also that it was correct not to invoke the nondelegation doctrine in the case. In a period in which the Court is often criticized for allowing its own political convictions to overwhelm its duty of fidelity to the law, the quiet, lawyer-like analysis in ATA warrants considerable enthusiasm. I also argue on behalf of a large role, even after $A T A$, for the cost-benefit default principles, suggesting that they deserve a continuing place in the lower courts. In the process, I investigate one of the most interesting features of ATA: the sharply conflicting approaches of the Court's two specialists in administrative law. Justice Scalia's opinion for the Court is lawyerly, formalistic, textualist, and apparently indifferent to the topic of consequences. Justice Breyer's concurring opinion is highly pragmatic, going well beyond the legal materials to try to make sense of the regulatory regime that Congress created. With respect to the law of risk regulation, I believe that Justice Breyer's opinion, an unambiguous rejection of 1970s environmentalism, is the harbinger of the future, and potentially the most important opinion in the case. Invoking Justice Breyer's concerns, I suggest that a number of challenges remain

${ }_{17}$ See American Trucking Assn. v. EPA, 175 F.3d 1027 (DC Cir 1999). 
available to national ambient air quality standards - and that the most plausible of these challenges, connected directly with Justice Breyer's opinion, promise to increase the sense and rationality of national environmental policy.

This Article comes in four parts. Part I describes the background. Part II discusses the Court's opinion and offers an evaluation. Part III briefly explores the three concurring opinions in the case, with particular reference to Justice Breyer's emphasis on recurring issues in risk regulation. Part IV discusses the future. I pay special attention here to the problems not resolved in ATA, including the place of cost-benefit default principles, constitutional status of the Occupational Safety and Health Act (OSHA), and the possibility of nonconstitutional challenges to the EPA's particulates and ozone regulations, and indeed ambient air quality regulations in general.

\section{The Setting}

To understand ATA, it is necessary to know something about what happened in the EPA and the court of appeals. For many years, the EPA had refused to issue a new national standard for particulates, notwithstanding scientific evidence apparently indicating grounds for action. Eventually the EPA was spurred to act by a decision of a district court, with an exceedingly rapid timetable for action. ${ }^{18}$

So spurred, the EPA issued a new standard for small particulates in 199719; at the same time, the EPA issued a standard for ozone. In both cases, the scientific issues are extremely complex, and reasonable people might well argue about whether the evidence adequately supported the EPA's decisions. But a general reading of the evidence suggests an important distinction, one that is relevant both to ATA and to the future of risk regulation. Under the EPA's own data, the particulates standard promises significant health gains, both in terms of mortalities averted and in terms of morbidity. ${ }^{20}$ Consider the following table:

\footnotetext{
${ }^{18}$ See American Lung Association v. Browner, 884 F. Supp. 345 (D. Ariz. 1994).

${ }^{19} 62$ Fed. Reg 38,652 (1997).

20 The clearest evidence comes from U.S. EPA Innovative Strategies \& Economics Group, Office of Air Quality Planning and Standards, Regulatory Impact Analyses for the Particulate Matter and Ozone National Ambient Air Quality Standards (1997). For an overview, see appendix to Cass R. Sunstein, Is the Clean Air Act Unconstitutional?, 98 Mich L Rev 303, 384-94 (1999).
} 
Table 1

Particulates Standard

National Annual Health Incidence Reductions

\begin{tabular}{|c|c|c|}
\hline ENDPOINT & & Partial Attainment Scenario \\
\hline & Annual PM $\mathbf{P M}_{2.5}$ & 50 \\
\hline & Daily $\mathbf{P M}_{2.5}$ & 150 \\
\hline & 360 \\
\hline \multicolumn{2}{|c|}{ long-term exposure } & 340 \\
\hline \multicolumn{2}{|c|}{ 2. Chronic Bronchitis } & 6,800 \\
\hline \multicolumn{3}{|c|}{ Hospital Admissions: } \\
\hline \multicolumn{2}{|c|}{ 3. all respiratory (all ages) } & 190 \\
\hline \multicolumn{2}{|c|}{ all resp. (ages 65+) } & 470 \\
\hline \multicolumn{2}{|c|}{ pneumonia (ages 65+) } & 170 \\
\hline \multicolumn{2}{|c|}{ COPD (ages 65+) } & 140 \\
\hline \multicolumn{2}{|c|}{ 4. Congestive heart failure } & 130 \\
\hline \multicolumn{2}{|c|}{ 5. Ischemic heart disease } & 140 \\
\hline \multicolumn{2}{|c|}{ 6. Acute Bronchitis } & 1,100 \\
\hline \multicolumn{2}{|c|}{ 7. Lower Respiratory Symptoms } & 10,400 \\
\hline \multicolumn{2}{|c|}{ 8. Upper Respiratory Symptoms } & 5,300 \\
\hline \multicolumn{2}{|c|}{ shortness of breath } & 18,300 \\
\hline \multicolumn{2}{|l|}{ asthma attacks } & 8,800 \\
\hline \multicolumn{2}{|l|}{ 9. Work Loss Days } & 106,000 \\
\hline \multicolumn{2}{|c|}{ 10. Minor Restricted Activity Days (MRADs) } & 879,000 \\
\hline
\end{tabular}

But EPA data suggest a much more mixed picture for ground-level ozone. The evidence is more mixed for two reasons. First, the mortality and health gains from the new standard appear much more modest; it is possible that the ozone standard would save no additional lives per year. Indeed, tighter regulation of particulates, going well beyond the EPA's rule, would appear to do a great deal more to protect health than would the new regulation of ozone. Consider the following table: 
Table 2 Ozone Standard

\begin{tabular}{|c|c|}
\hline ENDPOINT & \\
\hline & $\begin{array}{c}0.08 \text { 4th Max } \\
\text { Low- to High-end Est. }\end{array}$ \\
\hline $\begin{array}{l}\text { Ozone Health: } \\
\text { 1. Mortality }\end{array}$ & $0-80$ \\
\hline $\begin{array}{l}\text { Hospital Admissions } \\
\text { 2. all respiratory (all ages) } \\
\text { all respiratory (ages 65+) } \\
\text { pneumonia (ages 65+) } \\
\text { COPD (ages 65+) } \\
\text { emer. dept. visits for asthma }\end{array}$ & $\begin{array}{c}300-300 \\
2,330-2,330 \\
870-870 \\
260-260 \\
130-130\end{array}$ \\
\hline $\begin{array}{l}\text { 3. Acute Respiratory Symptoms } \\
\text { (any of 19) } \\
\text { asthma attacks } \\
\text { MRADs }\end{array}$ & $\begin{array}{c}29,840-29,840 \\
60-60 \\
650-650\end{array}$ \\
\hline 4. Mortality from air toxics & $1-1$ \\
\hline $\begin{array}{l}\text { Ancillary PM Health: } \\
\text { 1. Mortality: short-term exp. } \\
\text { long-term exposure }\end{array}$ & $\begin{array}{c}0-80 \\
0-250\end{array}$ \\
\hline 2. Chronic Bronchitis & $0-530$ \\
\hline $\begin{array}{l}\text { Hospital Admissions: } \\
\text { 3. all respiratory (all ages) } \\
\text { all resp. (ages 65+) } \\
\text { pneumonia (ages 65+) } \\
\text { COPD (ages 65+) } \\
\text { 4. congestive heart failure } \\
\text { 5. ischemic heart disease }\end{array}$ & $\begin{array}{l}0-90 \\
0-60 \\
0-20 \\
0-20 \\
0-20 \\
0-20\end{array}$ \\
\hline 6. Acute Bronchitis & $0-400$ \\
\hline $\begin{array}{l}\text { 7. Lower Respiratory Symptoms } \\
\text { 8. Upper Respiratory Symptoms } \\
\text { shortness of breath } \\
\text { asthma attacks }\end{array}$ & $\begin{array}{c}0-4,670 \\
0-430 \\
0-1,220 \\
0-5,510\end{array}$ \\
\hline 9. Work Loss Days & $0-50,440$ \\
\hline 10. Minor Restricted Activity Days (MRADs) & $0-420,300$ \\
\hline
\end{tabular}


Second, the evidence for ozone is more mixed because ground-level ozone provides protection against cataracts and skin cancer. ${ }^{21}$ To be sure, cataracts and skin cancer are not the most serious of health problems, especially in light of the very high cure rate for skin cancer. But if the protective effects are taken into account, it is not entirely clear that the new regulation of ozone will actually produce a net improvement in terms of health.

The relevant provision of the Clean Air Act requires the EPA to set primary standards "the attainment and maintenance of which ... are requisite to protect the public health," with "an adequate margin of safety." 22 The American Trucking Association and others launched a variety of challenges to the particulates and ozone standards. Of these challenges, among the most interesting was based on the evidence just described -- a claim that the EPA was obliged to take into account the health benefits, and not merely the health risks, of ground-level ozone. The court accepted this objection, concluding that the EPA had consider all "identifiable effects" of ozone, both positive and negative. ${ }^{23}$ The government did not appeal this important aspect of the decision, whose implications for future EPA action remain unclear, in part because of the EPA's unenthusiastic response to the ruling. ${ }^{24}$

But the two major rulings of the court of appeals involved even larger issues. In the court's view, the statute simply did not allow the agency to consider costs, and hence a cost-blind approach to statutory standard was not merely permissible but required. ${ }^{25}$ In this way the court rejected American Trucking Association's imaginative effort to produce a large-scale departure from the longstanding understanding that national ambient air quality standards would be set without regard to costs. But construed as a "benefits only" provision, the court thought that the relevant provision of the CAA raised extremely serious constitutional problems under the nondelegation doctrine, which grows out of the constitutional vesting of "all legislative power" in "a Congress of the United States." 26 The reason for the constitutional difficulty was

\footnotetext{
${ }^{21}$ See Randall Lutter and C. Wolz, UV-B Screening by Tropospheric Ozone: Implications for the National Ambient Air Quality Standard, 31 Env. Science \& Tech. 142A (1997); Randall Lutter and Howard Gruenspecht, Assessing Benefits of Ground-Level Ozone: What Role for Science in Setting National Ambient Air Quality Standards (unpublished manuscript 2001).

2242 USC 7409(b)(1).

${ }^{23}$ American Trucking Assns. V. EPA, 175 F.3d 1027 (DC Cir 1999).

${ }^{24}$ For an overview, see Lutter and Gruenspecht, supra note.

${ }^{25}$ See id. for an outline and for critical discussion.

${ }^{26}$ United States Constitution, Article 1, section 1.
} 
simple: The relevant provision, as interpreted by EPA, seemed to allow the agency to choose whatever standard it liked best. "The agency rightly recognizes that the question is one of degree, but offers no intelligible principle by which to identify a stopping point." 27 In the court's view, "EPA's formulation of its policy judgment leaves it free to pick any point between zero and a hair below the concentrations yielding London's Killer Fog." ${ }^{28}$ The Constitution could not be satisfied without some clearer principle distinguishing permitted from prohibited regulation. Rather than invalidating the statute, however, the court allowed EPA to cure the difficulty. In the court's view, it remained possible that the EPA could construe the statute in a way that would remove the constitutional doubts. ${ }^{29}$ Such a narrowing construction would be both necessary and sufficient for validity.

But what, specifically, did the court have in mind? The question is important both for understanding the Supreme Court's decision in ATA and for understanding the future of national standards after ATA. Clearly the court of appeals sought a high degree of quantification - indeed a high enough degree of quantification to allow the EPA to explain, with some precision, why one standard would be "requisite" to protect the public health, while other standards would not be. In this way, the court signaled its interest in moving well beyond 1970s environmentalism, toward an approach that would rely on numbers rather than general concern and overall impressions. Above all, the court sought a specification of the kinds of numbers - in terms of likely adverse health effects under the existing standard -- that would call for increased regulation, and the kinds of numbers that the EPA would consider tolerable, and hence would not call for increased regulation. In the key passage, the court wrote: "On the issue of likelihood, for some purposes it might be appropriate to use standards drawn from other areas of the law, such as the familiar 'more probable than not' criterion. Of course a one-size-fits-all criterion of probability would make little sense. .. . Nonetheless, an agency wielding the power over American life possessed by the EPA should be capable of developing the rough equivalent of a generic unit of harm that takes into account population affected, severity, and probability...." ${ }^{\prime 30}$

27 I75 F. 3d at 1036.

${ }^{28}$ Id. at 1037.

${ }^{29} \mathrm{Id}$. at 1039.

${ }^{30} \mathrm{Id}$. 
What the court apparently sought was some sort of general measure of adverse effects, one that would give an explanation of why, in any given case, the agency regulated to one "point" rather than another. The agency might, for example, value a statistical death at "100," treat a case of chronic bronchitis as some fraction of that, and do the same for every other adverse health effect. The universe of harms from exposure might well be aggregated in this way - so that the gains from the chosen level of regulation would be $X$, whereas the gains from less stringent regulation would be $80 \%$ of $X$, and the gains from more stringent regulation would be $120 \%$ of $X$. With quantification of this sort, it would be possible to know why the agency chose one point rather than another for particulates and ozone, and also to ensure that the agency's particular choices squared, more or less well, with its particular choices for other pollutants. The result would be to ensure cross-pollutant coherence, and also to provide some coherent explanation, in specific cases, of why industry is wrong to urge less stringent controls, and why environmentalists are wrong to request more stringent controls.

Perhaps the court suggested this "generic unit of harm" approach partly because of the odd fact that the particulates and ozone regulations were before it in the same case - and because it seemed hard to understand why EPA did not regulate particulates more stringently, and ozone less so. Of course there are many complexities in doing what the court of appeals sought. To give just one illustration, it is not clear if the agency should focus on the probability of harm faced by each individual, or instead on some statistical measure of aggregate harms, faced by the population as a whole. ${ }^{31}$ But the EPA does have sufficient information to produce some sort of overall measure of harm, in a way that would satisfy the court's concerns..$^{32}$ A key question is whether the Constitution, or some other source of law, requires the EPA to be so quantitative, as a way of explaining why it chooses one degree of regulation rather than another, either more or less stringent.

The government promptly appealed, objecting above all to the nondelegation ruling. In a bit of a surprise, the respondents cross-petitioned, arguing that the Act should be construed to allow the EPA to consider costs in setting ambient standards. The cross-petition was analytically prior, and this was the question that the Supreme Court addressed first.

\footnotetext{
${ }^{31}$ For a plea for looking at the size of the affected population, see James Hamilton and W. Kip Viscusi, Calculating Risks (1999).

32 See Sunstein, supra note, for an overview, with reference to ozone and particulates.
} 


\section{Lawyer's Fare}

Let us now turn to the Court's rulings on the two key issues in the case..$^{33}$

\section{A. Costs? No Elephants in Mouseholes}

The first question was whether national ambient air quality standards should be based on an assessment of benefits alone, or instead on some kind of balancing of benefits and costs. Recall that the relevant provision of the CAA requires the EPA to set primary standards "the attainment and maintenance of which ... are requisite to protect the public health," with "an adequate margin of safety." At first glance, the statute appears to be indifferent to cost. All that matters is that pollution be controlled so as "to protect the public health." This view of the provision is strengthened by the fact that national standards are supposed to be based on a "criteria" document, which is required, in turn, to discuss all "identifiable effects" of the pollutant on public health and welfare. ${ }^{34}$ The criteria document is not required to discuss the economic effects of regulation itself. Thus the analysis seemed simple: If the ambient standard is required "to protect the public health" and to be "based" on the criteria document, and if that document is not supposed to discuss costs, then it would seem to follow that standard-setting may not be done with reference to costs.

In essence, the Court accepted this analysis. Proceeding in textualist manner, with an emphasis on statutory language and structure (but no reference to the legislative history), it held that standard-setting must indeed be costblind. ${ }^{35}$ The Court said that the key statutory term, "public health," requires an analysis of the effects of the pollutant, and that costs are irrelevant. But the American Trucking Association and its allies pressed some good questions from common sense: Can the EPA possibly issue national standards on the basis of an inquiry into public health only? If the costs of compliance are extremely high, won't the EPA inevitably impose more lenient regulations than it would if the costs are extremely low? Isn't it obviously worthwhile to achieve some small improvement in air quality, if the costs of compliance are (say) $\$ 500,000$, and obviously less worthwhile to do so if the costs of compliance are (say) $\$ 10$ billion? These questions seem especially powerful in light of the fact,

\footnotetext{
${ }^{33}$ I do not discuss the third ruling, involving the relationship between the new ozone rule and statutory provisions governing ozone. This third ruling has considerable practical importance, but it does not raise recurring issues.

${ }^{34} 42$ USC 7409(b)(1).

35121 S. Ct. at 911.
} 
acknowledged by EPA, that there is no "safe threshold" for many pollutants, including those involving in ATA itself. If there is no safe threshold, a cost-blind analysis would seem to require EPA to eliminate pollutants from the ambient air - a result that would ban automobiles, coal-fired power plants, and much more. Consideration of costs would appear necessary to avert this ludicrous conclusion. And the argument seemed to draw further strength from the apparent fact, urged by credible observers, that the EPA had in fact considered costs, although tacitly and without public supervision. ${ }^{36}$

In fact it makes most sense to interpret the "requisite to protect the public health" language to require EPA to make a showing of significant risk, a point that goes some (not all) of the way toward answering these objections. ${ }^{37}$ But the Supreme Court's major answer to these points was simple: Tell it to Congress. ${ }^{38}$ For the Court, the only real question was whether "public health" could be understood to be a reference not only to environmental effects, but also to the adverse effects introduced by regulation. Invoking the dictionary ${ }^{39}$ as its principal authority, the Court suggested (not so helpfully) that the ordinary meaning "public health" is "the health of the public," that this is "the most natural of readings," and that the natural reading is inconsistent with the claim that costs are relevant to the EPA's decision. ${ }^{40}$

To be sure, the cross-petititioners did not rely on policy arguments alone. They also urged (and the Court acknowledged, also with the dictionary's aid) that "public health" is a not an unambiguous phrase. In their view, "many more factors than air pollution affect public health," and "a very stringent standard might produce health losses sufficient to offset the health gains achieved in cleaning the air - for example, by closing down whole industries and thereby impoverishing the workers and consumes dependent upon those industries." ${ }^{41}$ There is a great deal of evidence to support this claim. Expensive regulation does appear to produce health risks. ${ }^{42}$

\footnotetext{
${ }^{36}$ See Marc Landy et al., The Environmental Protection Agency: Asking the Wrong Questions (1997).

${ }^{37}$ As Justice Breyer emphasized. See below.

${ }^{38}$ Id.

${ }^{39}$ Use of the dictionary has become a common textualist theme. See Note, Looking It Up, 107

Harv. L. Rev. 1437 (1995); William Eskridge, The New Textualism, 37 UCLA L Rev 621 (1990).

40121 S. Ct.. at 908.

${ }^{41}$ I.d at 909.

${ }^{42}$ See Robert Hahn et al. Do Federal Regulations Reduce Mortality? (2000).
} 
The Court did not reject the empirical claim, but it held that arguments of this kind could not defeat the "natural" interpretation of the Act. Indeed the Court analyzed the statutory structure to give further support to that interpretation. Unlike the apparently cost-blind provision governing national ambient air quality standards, other provisions of the Clean Air Act explicitly permitted cost to be taken into account. For example, a key provision of the Act, for example, asks EPA to consider costs in selecting the "best system" for emissions reductions from new pollution sources. ${ }^{43}$ The fact that some statutes expressly referred to cost seemed to support the view that the provision at issue in ATA, most naturally read as cost-blind, did in fact have this meaning. To this the Court added that Congress was "unquestionably aware" of the potentially adverse effects of expensive regulation, and hence allowed the EPA to waive the compliance deadline for stationary sources upon a showing, inter alia, that "the continued operation of such sources is essential ... to the public health or

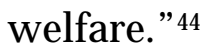

All this was enough to suggest that the basic provision of the Act banned consideration of cost. Because that basic provision is "the engine that drives nearly all" 45 of the subsequent provisions of the Act, Congress would not lightly be taken to have required cost consideration in other provision. ${ }^{46}$ Congress "does not alter the fundamental details of a regulatory scheme in vague terms or ancillary provisions - it does not, one might say, hide elephants in mouseholes." ${ }^{77}$ Hence the statute's terms "adequate margin" and "requisite" should not be taken to allow consideration of cost, because it is "implausible that Congress would give to the EPA through these modest words the power to determinate whether implementation costs should moderate national air quality standards." ${ }^{48}$ To be sure, a number of provisions of the Act expressly require the EPA to generate information about compliance costs. ${ }^{49}$ But in the Court's view, these provisions are designed to allow the EPA to assist the states in finding lowcost strategies for attainment. ${ }^{50}$ They do not suggest that EPA is allowed to

\footnotetext{
4342 USC 7411(b)(1)(B).

44121 S. Ct. at 909.

${ }^{45}$ This is a considerable overstatement, to the point of inaccuracy. A number of provisions of the CAA are affected by the national ambient air quality standards, but most of the (countless) provisions are not affected by national standards.

${ }^{46}$ Id. at 910.

${ }^{47}$ Id. at 910.

${ }^{48}$ Id. at 910.

4942 USC 7408(b)(l).; 42 USC 7409(d)(2)(C)(iv).

50121 S. Ct. at 911.
} 
consider costs on its own. All these considerations converged on a single conclusion: Ambient standards must be based on considerations of health, and cost simply does not matter.

\section{B. Delegation?}

If the EPA's task is to assess public health alone, is the statute an unconstitutional delegation of power? Common sense might suggest that there is a serious problem here. The question of what level is "requisite to protect the public health" seems unaccompanied by statutory standards. If there are no safe thresholds, perhaps EPA could (must?) require some pollutants to be eliminated entirely from the ambient air. But even in the absence of safe thresholds, perhaps EPA could decide that certain risks are to be treated as residual, ordinary, the stuff of everyday life. If the statute does not tell the agency what it must do, perhaps its range of discretion is unacceptable. Note in this regard that many people do not believe that certain imaginable steps are "requisite" to protect their own health: They walk at night in dangerous neighborhoods; they eat peanut butter; they fail to exercise; they gain weight; they drive cars; they own large dogs. In all of these cases, the risks may well be nontrivial as a statistical matter, and perhaps EPA could build on such practices in deciding what level of regulation is "requisite." But without statutory guidance, perhaps the Act gives the EPA excessive discretion - the discretion essentially to choose the level of risk regulation that it wants, with essentially no legislative guidance.

It is important to say here that a statute requiring cost-benefit balancing might, on this line of reasoning, raise similar nondelegation issues, at least in the absence of legislative guidance on how to assess both costs and benefits. Without such guidance, is an agency permitted to say that a statistical life is worth $\$ 1$ million? \$10 million? \$50 million? Can an agency discount lives saved in the future? By $1 \%$ ? By $7 \%$ ? If the statute allows agencies to value statistical lives as they choose, there might seem to be an unacceptably high level of discretion. Thus a constitutional attack on the "requisite to protect the public health" language would doubts about many other provisions, including those that give costs a role to play in regulatory choices. ${ }^{51}$

Troubled by the wide range of discretion apparently enjoyed by the EPA, the court of appeals held that the Constitution required the agency to come up with clear standards by which to explain why it would exercise its discretion to

\footnotetext{
${ }^{51}$ See Sunstein, Is the Clean Air Act Unconstitutional?, supra note, for discussion.
} 
regulate to one "point" rather than another. But as a constitutional matter, the Supreme Court found the lower court's approach quite implausible. "In a delegation challenge, the constitutional question is whether the statute has delegated legislative power to the agency." 52 Because this is the question, an agency cannot "cure" an otherwise unconstitutional delegation of power merely by adopting a narrowly construction. "The idea that an agency can cure an unconstitutionally standardless delegation of power by declining to exercise some of that power seems to us internally contradictory." ${ }^{53}$ Thus the agency's "voluntary self-denial"54 has no bearing on the real constitutional question, which is whether Congress has cabined agency discretion with the requisite "intelligible principle."

Turning to that question, the Court said that the statute required the EPA to use the latest scientific knowledge to establish standards "at a level that is requisite to protect the public health from the adverse effects of the pollutant in the ambient air." The statutory idea of "requisite-to-protect" meant "sufficient, but not more that necessary," to provide that protection. ${ }^{55}$ In the Court's view, this standard was constitutionally acceptable, because it was "strikingly similar" to limitations found acceptable in other cases. The Court had, for example, upheld a grant of authority to the Attorney General to designate a drug as a controlled substance if this step was "necessary to avoid an imminent hazard to the public health." 56 The Occupational Safety and Health Act contained a quite similar provision, which was also found constitutionally valid. ${ }^{57}$ The Court acknowledged that "the degree of agency discretion that is acceptable varies according to the scope of the power congressionally conferred." 58 Hence Congress "must provide substantial guidance on setting air standards that affect the entire national economy." ${ }^{29}$ But it was nonetheless unnecessary for Congress to provide a "determinate criterion" to establish how much regulation is too much. To be sure, the EPA would be making "judgments of degree." The decision about what is "requisite" would not run afoul of the nondelegation principle.

$52121 \mathrm{~S} \mathrm{Ct}$ at 912.

${ }^{53} \mathrm{Id}$.

${ }^{54} \mathrm{Id}$.

${ }^{55}$ Id. at 912.

56 Touhy v. United States, 500 S 160 (1991).

${ }^{57}$ Industrial Union Department, AFL-CIO v. API (The Benzene Case), 448 US 607 (1980).

58121 S. Ct. at 913.

${ }^{59} \mathrm{Id}$. 


\section{Evaluation: Two and A Half Cheers}

On both of the key issues, the Court's unanimity should not be surprising. Indeed, the Court's fidelity to preexisting law -- even its steady, unimaginative, lawyerly opinion -- gives reason for some confidence in a Court that has been much criticized for allowing its own political convictions to play an excessive role in its interpretation of the law. It is far from unreasonable to speculate that some of the justices lacked much enthusiasm, on political grounds, for a costblind Clean Air Act, and that some of them would like Congress to give narrower delegations of authority to regulatory agencies. Nonetheless, the Court took the existing legal materials, in the form of statutory language and judicial precedents, extremely seriously. The Court was right to say that those materials required both results. The best interpretation of the CAA does not allow the EPA to consider costs when setting national standards. Moreover, there is no good argument for a large-scale revival of the nondelegation doctrine; and if the doctrine is to be used in the most extreme cases, ATA was not such a case.

1. Cost. To say this is not to deny that the case had its complexities, or to urge that it would be impossible to imagine an opinion coming out the other way on either issue. At a minimum, the Court might plausibly have said that in deciding what margin of safety is "adequate," the EPA is permitted to take account of costs, not merely benefits. In addition, the phrase "requisite to protect the public health" is not altogether transparent. Especially in view of the fact that expensive regulations can have harmful effects on public health - a fact of which Congress was aware - it could be urged that whether a particular regulation qualifies, under that phrase, as "requisite" is a function of cost, not merely benefit. A reasonable court might well be drawn to this interpretation, at least if it were seen as the only way of making sense, rather than nonsense, of the statute as a whole. Such an opinion would not have been beyond the pale.

Nor would this approach entirely lack precedential support. In the Benzene Case, ${ }^{60}$ the Court interpreted the Occupational Safety and Health Act in a way that would ensure against regulatory absolutism - not by requiring costbenefit balancing, but by saying, without textual support, that the agency could not regulate a risk not shown to be "significant." In dissent, Justice Marshall, sounding very much like Justice Scalia in ATA, contended that conventional legal tools could not justify imposing a "significant risk" requirement, which, in

${ }^{60}$ Industrial Union Department, AFL-CIO, v. API, 448 US 607 (1980). 
Justice Marshall's view, was a judicial fabrication. ${ }^{61}$ In defending its conclusion, and its somewhat irreverent approach to the statutory text, the Benzene plurality emphasized that the government's approach "would give OSHA power to impose enormous costs that might produce, little, if any, discernible benefit." 62 It would not have been a gigantic stretch from this line of reasoning to a holding, in ATA, that the EPA should be permitted to consider whether an enormous outlay of expenditures can be justified by the benefits received. In any case a number of lower court decisions have not stayed close to the statutory text where common sense seemed to require a measure of regulatory flexibility. ${ }^{63}$

Nonetheless, the path that the Court chose was unquestionably the easier one, because it fit so much more naturally with the statutory language. To this we might add three further points. First, the pressure on the Court was greatly relieved by the fact that in the implementation process, costs could indeed be considered, and at multiple stages. This point sharply distinguished the CAA from OSHA, which lacks any comparable implementation stage. ${ }^{64}$ If Justice Scalia's majority opinion in ATA is close to Justice Marshall's dissenting one in the Benzene Case, it might be partly because the consequences of a cost-blind approach to standard-setting are not quite what they seem - as Justice Scalia was undoubtedly aware. Second, the "requisite to protect the public health" language might well be regarded as imposing a significant risk requirement. The Court said little on this issue, a gap to which I will turn in due course; but even on the Court's view, the CAA does not require the EPA to remove all risks, regardless of their magnitude. For this reason the EPA's position in ATA was far more cautious, and modest, than OSHA's more draconian position in the Benzene Case. Third, textualism might be regarded as a kind of "penalty default," imposing a burden on Congress, and on relevant interest groups, to provide a corrective for any problems introduced by a cost-blind approach. There is room for reasonable debate about whether Congress is sufficiently responsive to penalty defaults of this kind. But some comfort can come from the fact that a legislative corrective is certainly possible, and has in fact been provided in a somewhat analogous context. ${ }^{65}$

\footnotetext{
${ }^{61} \mathrm{Id}$ at 640 (Marshall, J., dissenting).

62 Id. at 620.

${ }^{63}$ See, eg., State of Michigan v. EPA, supra.

${ }^{64}$ This is because the CAA requires states to produce implementation plans to bring about compliance with federal standards, whereas OSHA regulations are directly binding on the private sector.

${ }^{65}$ See 21 USC 376(b)((5)(B) (the Delaney Clause), as discussed in Public Citizen v. Young, 831 F2d 1108 (DC Cir 1987). In 1996, Congress amended the Delaney Clause in various ways, softening its
} 
2. Delegation. On the nondelegation issue, the Court's opinion is much less satisfying. The Court appears to have delivered a death blow to those who have sought to revive the nondelegation doctrine. Why, exactly, did the Court do this? The Court's opinion is quite wooden on the point, attempting only to show that the delegation in the CAA was no different from those delegations found acceptable in many other cases. This was an example of dullest and the most unambitious form of analogical reasoning - the sort of thing recently associated with Chief Justice Rehnquist, or even former Chief Justice Burger, and very different from what usually emerges from the Justice Scalia's pen.

Most strikingly, the Court made no effort to explain exactly why it was so willing to allow Congress to grant considerable discretionary authority to the EPA. Nor did the Court explain why it was uninterested in reviving the nondelegation doctrine in general. With respect to analogies, the Court basically skimmed the surface, arguing, plausibly if not entirely convincingly, that the delegation here was not evidently greater than the delegation in other cases. The Court offered exceedingly little in the way of detail. It would not have been terribly hard to distinguish those cases. The EPA, for example, is authorized to cover a much larger portion of the American economy than was involved in the precedents, and it would be at least plausible to say that its discretion was broader as well. To know whether this latter argument is convincing, it would be necessary to say much more about the meaning of the relevant provision of the Clean Air Act. But here the Court's efforts were thin to the point of being comical. The repetition of statutory terms - "requisite to protect the public health" - was not much aided by the Court's (repeated) explanation that these terms meant "no less, but also no more" than necessary to protect the health of the public.

We might say that with respect to the nondelegation doctrine, the Court's opinion is remarkably shallow, in the sense that it lacks any theoretical ambition, but also remarkably wide, in the sense that it appears to dispose of a wide range of imaginable nondelegation challenges. ${ }^{66}$ The Court has made it clear that the nondelegation doctrine will be used, if at all, only in the most extreme cases. But

absolutist character. See 21 USC 321 (d), by replacing the flat ban with a requirement of a "reasonable certainty of no harm," defined in the legislative history to reflect a policy of reducing cancer risks in the exposed population to no more than 1-in-1-million additional lifetime risk. For discussion, see Robert Percival et al., Environmental Regulation 496 (3d ed. 2001).

${ }_{66}$ On shallowness/depth and narrowness/breadth, see Cass R. Sunstein, One Case At A Time (199). 
it has given little indication of why it is taking this approach. Is it possible to say what lies beneath the surface here?

Some clues come from Justice Scalia's separate writing on the topic. ${ }^{67}$ Justice Scalia has objected to the nondelegation doctrine on the ground, not that it lacks constitutional roots, but that it is not subject to principled judicial enforcement. The line between permissible and prohibited delegations is inevitably one of degree: How much discretion is too much discretion? Judicial efforts to answer that question are not susceptible to rule-bound judgments, and hence particular rulings would inevitably have the appearance, and perhaps the reality, of judicial partisanship. In these circumstances a judicially enforcement nondelegation doctrine might even be said to violate that very doctrine's aspiration to rule-bound law. A judge who aspires to reduce judicial discretion will inevitably be skeptical about the nondelegation doctrine.

I believe that these concerns help explain the Court's surface-skimming in ATA - and also that the concerns are well-founded. These institutional problems are best combined with a point about the nature of the regulatory state. There is no good evidence that a revival of the nondelegation doctrine would make constitutional government work better, from any point of view. In this light the case for reviving the doctrine seems weak indeed. ${ }^{68}$ Indeed, the purposes underlying the doctrine can better be achieved through other routes, including substantive reform, the hard look doctrine, and narrowly targeted "nondelegation canons. ${ }^{\prime 69}$

But all this leaves a nagging question: What does the Act mean? Here the Court's answer is embarrassingly thin. The respondents urged that the statutory standard - "requisite to protect the public health" - could mean anything at all. To respond to their complaint, it would be necessary to explain how the standard creates ceilings and floors on agency action. I will return to the question in Part IV.

\footnotetext{
${ }^{67}$ See Mistretta v. US, 488 US 361, 375 (1989) (Scalia, J., concurring in part and dissenting in part).. ${ }^{68}$ See Cass R. Sunstein, supra note.

${ }^{69}$ See Cass R. Sunstein, Nondelegation Canons, in Designing Democracy: What Constitutions Do (forthcoming 2001).
} 


\section{Fundamentalism, Semantics and Pragmatism}

ATA produced three separate opinions of considerable interest. Justice Thomas' concurring opinion is noteworthy because of his brief remarks on the nondelegation doctrine. Justice Stevens' far longer concurrence is noteworthy because of the "caveat" he seeks to add to the majority's view. Justice Breyer's opinion is the most important of all, because of its effort to make sense of the regulatory scheme, and because of its attempt to provide some guidance for the future of risk regulation. Before exploring the majority opinion, I offer a brief outline and several comments here.

\section{A. Fundamentalism}

Justice Thomas agreed that the CAA provided "no less an 'intelligible principle' than a host of other directives that we have approved."70 But he objected that the parties had provided "barely a nod to the text of the Constitution," which does not speak of 'intelligible principles'"'71 Instead, he urged, "it speaks in much simpler terms: All legislative powers herein granted shall be vested in a Congress.'" In Justice Thomas' view, some statutes might contain "intelligible principles" but still involve a delegated decision whose significance "is simply too great . . . to be called anything other than legislative."72 For this reason, Justice Thomas indicated his willingness "to address the question whether our delegation jurisprudence has strayed too far from our Founders' understanding of separation of powers."73

At first glance, Justice Thomas' reasoning seems mysterious. The requirement of an "intelligible principle" is many decades old. ${ }^{74}$ It would be truly astonishing if the Court were to abandon the requirement as an understanding of the nondelegation principle. In any case the idea that "all legislative power" is vested in a Congress is hardly self-interpreting; the question is what this provision means. It would even be possible to read the constitutional background to suggest that Congress can delegate such legislative power as it wishes. If this conclusion is overdrawn-as I believe that it is ${ }^{75}$-then the question becomes when some amount of executive discretion becomes

\footnotetext{
70121 S. Ct. at 919.

${ }^{71}$ Id. at $919-920$.

72 Id. at 920.

${ }^{73}$ Id.

${ }^{74}$ See J.W. Hampton, Jr. v. US, 276 US 394, 409 (1928).

${ }^{75}$ See Sunstein, supra note, for discussion.
} 
"legislative" in nature. The requirement of an intelligible principle is simply a means of answering that question.

But underneath the implausible formalist veneer, Justice Thomas might well have a point. His key sentence is this: "I believe that there are cases in which the principle is intelligible and yet the significance of the delegated decision is simply too great for the decision to be called anything other than 'legislative.'"'76 Perhaps Justice Thomas is suggesting that an otherwise acceptable delegation would be objectionable if the area or context suggested - the "significance" indicated that an intelligible principle is not enough. So understood, Justice Thomas' view is not inconsistent with the majority's suggestion "that the degree of agency discretion that is acceptable varies according to the scope of the power congressionally conferred." On this view, the nondelegation doctrine is not entirely without life. Where an agency is given the power to regulate much of the American economy, the statutory principle must be more intelligible than it must otherwise be. All statutory principles must be intelligible, but some must be more intelligible than others. This is a perfectly reasonable suggestion.

\section{B. Semantics}

In an opinion joined by Justice Souter, Justice Stevens urged that the Court should admit that agency rulemaking authority counts as "legislative power," but that it is not unconstitutional for that reason. ${ }^{77}$ If national ambient air quality standards had been issued by Congress, "everyone would agree that those rules would be the product of an exercise of 'legislative power.'"78 In Justice Stevens' view, an agency that makes rules, under an acceptable delegation, is also acting "legislatively." For Justice Stevens, the proper way to analyze the case is to acknowledge that the agency acted legislatively, but to hold that the exercise of legislative power is legitimate, because it was constrained by a sufficiently intelligible principle.

This seems to be a purely semantic debate, and nothing at all appears to turn on it. Where the majority would say that legislative power had not been delegated, because an intelligible principle could be found, Justice Stevens would urge that the delegation of legislative power was acceptable, because an intelligible principle could be found. Justice Stevens was apparently writing for

\footnotetext{
76121 S. Ct. at 920.

${ }^{77} \mathrm{Id}$. at 920.

${ }^{78}$ Id. at 921.
} 
the sake of conceptual clarity. But it is unclear whether his approach counts as an improvement on that score. The Constitution vests legislative power in Congress, and on the standard view, legislative power cannot be delegated. In any event the executive has long had the power to make rules, and there is nothing odd in saying that rule-making, if confined by some principle, is an executive function if the executive is making rules. True, the same exercise would be legislative if Congress were carrying it out, a point that suggests that whether an activity counts as "legislative" or "executive" depends, in large part, on whether the Congress or the executive is acting. But where is the oddity in that conclusion? The Court's approach seems as sensible as that offered by Justice Stevens.

A good way to make progress would be to say that words, not excluding the word "legislative," have meanings connected with, and not divorced from, the purpose for which they are used. There is nothing odd in saying that rulemaking is "executive," when sufficiently cabined by statutory standards, when undertaken by the executive branch - but that the same sorts of decisions, if made by Congress, would be "legislative" when done by Congress. It seems to me that Justice Stevens has been lead astray by the ordinary language use of "legislative." Even if agency rulemaking is legislative in one, perfectly intelligible sense, it is not legislative, in the sense of Article I, section 1, if an executive agency has engaged in it.

\section{Pragmatism}

In its own way, Justice Breyer's opinion was the most remarkable in the case - an intriguing comparison to Justice Scalia's majority opinion, indeed an opinion that might easily be imagined as a majority opinion of a very different sort. Justice Breyer's separate opinion seemed to have two goals. The first was to show that the legislative history of the Act, and not merely its text, strongly supported the majority's conclusion. ${ }^{79}$ This part of Justice Breyer's opinion is part of a longstanding disagreement between Justice Scalia and Justice Breyer, ${ }^{80}$ and raises no novel problems.

Justice Breyer's second goal was to endorse a principle of interpretation, one that would allow agencies to consider costs in the face of statutory silence or ambiguity. "In order better to achieve regulatory goals—for example, to allocate

\footnotetext{
${ }^{79}$ Id. at 922.

${ }^{80}$ Compare Antonin Scalia, A Matter of Interpretation (1996) with Stephen Breyer, On the Uses of Legislative History in Interpreting Statutes, 65 So. Cal. L. Rev. 845 (1992).
} 
resources so that they save more lives or produce a cleaner environmentregulators must often take account of all of a proposed regulation's adverse effects, at least where those adverse effects clearly threaten serious and disproportionate public harm. Hence, I believe that, other things being equal, we should read silences or ambiguities in the language of regulatory statutes as permitting, not forbidding, this type of rational regulation." ${ }^{81}$ The reason that EPA could not consider costs here was that other things were not "equal"; the statutory structure and history showed "a congressional decision not to delegate to the agency the legal authority to consider economic costs of compliance." 82 This is a centrally important cautionary note, one to which I will return.

Justice Breyer's third goal was to establish the rationality of the legislative scheme as he understood it. He wanted to show that the "natural" construction made sense, not nonsense. His overall suggestion was that as construed, the statute would, at pertinent phases, allow consideration of costs after all, and that the EPA would be permitted to construe the statute reasonably, by making it less draconian than it appeared. To this end he offered four points, each of considerable interest.

1. As part of its cost-blindness, the statute was designed not to take pollution control technology as given but to force technological innovation. This was hardly an unrealistic hope..$^{83}$ In fact the catalytic converter was developed as a result of a seemingly draconian statutory mandate. And because the statute was expressly designed to force technological innovation, regulatory efforts to calculate the costs of compliance were "both less important and more difficult" relevant calculations would be based on speculation about the cost of unknown future technologies. These calculations "can breed timeconsuming and potentially unresolvable agreements about the accuracy and significance of cost estimates." ${ }^{\prime 85}$ In these circumstances, cost-benefit analysis might itself fail cost-benefit analysis.

2. Even as interpreted by the Court, the Act allows cost and feasibility to be considered. ${ }^{86}$ These factors are relevant, for example, to states deciding on the mix of control devices used to achieve compliance; and those facing

${ }^{81}$ Id. at 921.

82 Id. at $921-22$.

${ }^{83}$ Id. at 922.

${ }^{84}$ Id.at 923.

${ }^{85} \mathrm{Id}$.

${ }^{86} \mathrm{Id}$. 
economic hardship can seek an exemption from state requirements. The EPA is also permitted to consider costs, not in setting standards, but in setting deadlines for attainment. Congress is also available to extend deadlines if necessary. ${ }^{87}$ The relevant provision of the CAA might be costblind; but this is not at all true for the statute as a whole.

3. The EPA is not required to "eliminate every health risk, however slight, at any economic cost, however great." Standards "requisite to protect the public health" need not produce "a world that is free of all risk-an impossible and undesirable objective." ${ }^{88}$ In fact the terms "requisite" and "public health" should be understood in context. It is relevant for the EPA to consider "the public's ordinary tolerance of the particular health risk in the particular context at issue." Hence EPA is allowed to produce a kind of common law of "acceptable" risks, rather than eliminating all risks as such. In deciding what is "requisite to protect the public health," the EPA is allowed "to consider the severity of a pollutant's adverse health effects, the number of those likely to be affected, the distribution of the adverse effects, and the uncertainties surrounding each estimate." 89 On this count, Justice Breyer is saying more cautious than, but something not terribly far from, what was said by the court of appeals. In his own way, Justice Breyer was urging the EPA to develop standards for separating acceptable from unacceptable risks.

4. The EPA is allowed to "consider whether a proposed rule promotes safety overall." ${ }^{\prime 90}$ If a rule causes "more harm to health than it prevents," it is unlawful. ${ }^{11}$ In this wage Justice Breyer endorsed the lower court's conclusion that the EPA is required to consider the health benefits of ground-level ozone, not just the health risks.

What is most important about Justice Breyer's opinion is the effort not merely to read the statutory terms, but also to make sense out of them - to show that the statutory framework is not as silly, or absurd, as it might seem to be in the abstract. There is a noteworthy contrast here between Justice Scalia's approach, for the majority, and the approach favored by Justice Breyer. ${ }^{92}$ And

${ }^{87}$ Id.

${ }^{88}$ Id. at 924.

${ }^{89} \mathrm{Id}$.

${ }^{90} \mathrm{Id}$.

${ }^{91} \mathrm{Id}$.

${ }_{92}$ I will not discuss here the more general jurisprudential issues raised by formalism and pragmatism in statutory interpretation. A large issue is empirical - whether one or another approach can be defended on pragmatic grounds. If judges are undistinguished, formalism starts 
because it pays such attention to the pragmatic issues, Justice Breyer's opinion might well prove to be the more important for the future. Each of the four points just mentioned has significant implications for EPA decisions and indeed for regulation more generally, as we shall shortly see.

\section{Implications-and the Future}

ATA leaves many issues open. For the future, the three crucial questions involve (a) the place of the "cost-benefit default principles," which have played a large role in the last two decades of federal administrative law; (b) the status of the nondelegation doctrine; and (c) the legal standards governing ambient air quality standards, including the very standards involved in ATA. I discuss these issues in sequence.

\section{A. Cost-Benefit Default Principles}

The Court was well-aware that a number of lower court decisions have established a new interpretive principle: Where statutes are ambiguous, agencies are allowed to consider costs. ${ }^{93}$ What is the status of this principle, after ATA? While things are not entirely clear, the best answer is that the principle is unaffected. In fact Justice Breyer went out of his way to endorse the basic idea. ${ }^{94}$ Justice Breyer was careful to say that courts "should read silences or ambiguities in the language of regulatory statutes" to permit consideration of "all of a proposed regulation's adverse effects," at least where those effects would clearly be serious and disproportionate. ${ }^{\prime 95}$ For its part, the majority specifically referred to the cases establishing the principle and worked to distinguish them from the case at hand: "None of the sections of the CAA in which the District of Columbia Circuit has found authority for the EPA to consider costs shares [this provision's] prominence in the overall statutory scheme." ${ }^{\prime 96}$ Thus the Court was at pains to cite, with apparent approval, the key cases creating the basic principle, and appeared to be saying that the EPA might well be permitted to consider costs if the statute did not expressly forbid it from doing so.

to look a lot better; hence the best defenses of formalism are pragmatic in character. For the best discussion, see Adrian Vermeule, Interpretive Choice, NYU L Rev (2000); in the same spirit, see Cass R. Sunstein, Must Formalism Be Defended Empirically?, U Chi L Rev (1999).

${ }^{93}$ See, e.g., Michigan v. EPA, 213 F.3d 663, 678-79 (DC Cir 2000).

$94121 \mathrm{~S} \mathrm{Ct}$ at 921.

${ }^{95} \mathrm{Id}$.

${ }_{96} 121 \mathrm{~S} \mathrm{Ct}$ at $910 \mathrm{n} .1$. 
On the other hand, Justice Breyer was clearly concerned that the Court's approach would override the cost-benefit default principle. ${ }^{97}$ Justice Breyer urges that "In order better to achieve regulatory goals-for example, to allocate resources so that they save more lives or produce a cleaner environmentregulators must often take account of all of a proposed regulation's adverse effects, at least where those effects clearly threaten serious and disproportionate public harm. Hence, I believe that, other things being equal, we should read silences or ambiguities in the language of regulatory statutes as permitting, not forbidding, this type of rational regulation." 98 This point was meant as a rejoinder to the majority, which Justice Breyer took to be saying that to allow costs to be considered, Congress was required to be "clear." But at first glance, Justice Breyer's concern seems baseless. The Court was saying only that in view of the clarity of the main provision of the Clean Air Act, judges would be reluctant to find permission to consider costs elsewhere, since Congress "does not alter the fundamental details of a regulatory scheme in vague terms or ancillary provisions-it does not, one might say, hide elephants in mouseholes." ${ }^{\prime 9}$ This is a standard approach to statutory interpretation. It does not suggest that where a statute's "fundamental details" are vague, they will be interpreted to forbid consideration of cost.

But it would not be impossible to read the Court's opinion a bit more broadly. Recall that in concluding that EPA need not consider costs in issuing national standards, the Court emphasized that some provisions of the CAA explicitly refer to costs, and explicitly require them to be taken into account. Here the Court was using the canon of construction, "expressio unius est exclusio alterius": the expression of one thing is the exclusion of another. In the particular context of environmental statutes, the "expressio unius" canon could have explosive implications. When Congress does not explicitly refer to costs, agencies may not consider them, and for one simple reason: Congress often does explicitly refer to costs. If the canon is to govern the future, the cost-benefit default principles are in some trouble.

There is a further point. The Court seems to suggest that a statute should not be taken to confer broad discretionary authority on agencies: "We find it implausible that Congress would give to the EPA through these modest words the power to determine whether implementation costs should moderate national

\footnotetext{
97121 S. Ct. at 921.

98 Id. at 910

${ }^{99} \mathrm{Id}$.
} 
air quality standards." 100 To support the view that $A T A$ is best taken to disallow agencies to interpret ambiguous statutes to allow consideration of costs, it would be necessary to make a simple, two-step argument. First: Statutes should be construed so as to give agencies less rather than more in the way of discretion. Second: A construction of a statute that would allow agencies to decide whether to consider costs significantly increases agency discretion. Now the claim here is not that a statute requiring cost-benefit analysis is itself disfavored on delegation grounds. The claim is instead that an interpretation should be disfavored if the consequence of the interpretation would be to authorize the agency to decide whether to engage in cost-benefit balancing. If this claim is accepted, then the default rule in favor of allowing agencies to consider costs stands as repudiated.

But it is most unlikely that the Court would accept these lines of argument. The "expressio unius" canon can be a useful guide to statutory construction, and the more natural, cost-blind reading of "public health" is certainly supported by the fact that some provisions of the CAA make explicit reference to costs. But here as elsewhere, the "expressio unius" idea should be taken with many grains of salt. If Congress has not, under some ambiguous statutory term, referred to costs, it will often be because Congress, as an institution, has not resolved the question whether costs should be considered. And if this is so, the agency is entitled to consider costs if it chooses. ${ }^{101}$ The fact that Congress explicitly refers to costs under other provisions is not a good indication that, under an ambiguous text, costs are statutorily irrelevant. This would be an extravagant and therefore implausible inference. The use of the "expressio unius" approach in ATA is best taken as a sensible way of fortifying the most natural interpretation, and not at all as a way of urging that explicit references to cost, in some provisions, means that costs may not be considered under ambiguous provisions.

What about concerns about agency discretion? Agencies are typically allowed to interpret statutory ambiguities, ${ }^{102}$ and in countless cases in which that principle is invoked, the agency exercises a great deal of discretion over basic issues of policy and principle. ${ }^{103}$ To allow an agency to decide to consider costs is not to allow it to exercise more discretion than it does in numerous cases. Where the statute is unclear, agencies should be authorized to seek "rational regulation"; and nothing in ATA_suggests otherwise. This is especially so in light

$100 \mathrm{Id}$.

101 See Chevron v. NRDC, 47 US 837 (1984); see also note supra.

102 See Chevron v. NRDC, 47 US 837 (1984)..

103 See, e.g., id.; Babbitt v. Sweet Home Chapter, 515 US 687 (1995); Young v. Community Nutrition Institute, 476 US 974 (1986) 
of the fact, emphasized by both the Court ${ }^{104}$ and Justice Breyer, ${ }^{105}$ that the Clean Air Act allows EPA to consider costs at numerous stages in the implementation process. I conclude that ATA is best taken not to question the cost-benefit default principle, and indeed that the most reasonable reading of the opinion is that the Court has explicitly embraced that principle.

\section{B. Nondelegation Again? Nondelegation Ever?}

The Court's nondelegation ruling seems to be a kind of return to normalcy —as an effort to place the doctrine where it has been since 1935: In the constitutional coffin. This is a reasonable reading of the opinion, with the proviso that the doctrine remains available, now as before, for the extreme cases. What makes a case extreme? Apparently an extreme case would be one in which the agency has far more discretion than does the EPA under the "requisite to protect the public health" language. Cases of that sort are, by the logic of the Court's opinion, very few and far between. Schechter Poultry ${ }^{106}$ remains good law, and the Court was careful to say that when the area of agency authority is very broad, the statutory principle will certainly have to be intelligible. But the Court's basic message was that its own precedents suggest that almost all nondelegation challenges will be unavailing - and indeed that a mere repetition of any statutory standard will be a sufficient response.

1. An unusual line of cases. In one sense, however, the Court's nondelegation ruling was no mere a return to normalcy, and for a simple reason: It places some longstanding doctrine in disarray. In a series of cases, of which ATA was the culmination, the court of appeals for the District of Columbia circuit has held that a narrowing construction by an agency will be a sufficient and necessary condition for saving an otherwise objectionable delegation of authority. ${ }^{107}$ The doctrine originated in a challenge to the statute granting the President the authority to fix prices and wages. ${ }^{108}$ The relevant provisions appeared not to limit the President's discretion - to allow the President to set prices and wages however he chooses. In upholding the statute against constitutional attack, the court said not only that Congress had set out an intelligible principle, but also that the executive was

\footnotetext{
$104121 \mathrm{~S}$ Ct at 910.

105121 S. Ct. at 921.

106 ALA Schechter Poultry Corp. v. US, 295 US 495 (1935).

107 Amalgamated Meat Cutters v. Connally, 337 F Supp 737 (DDC 1971); International Union, UAW v. OSHA, 938 F.2d 1310 (DC Cir 1991); International Union, UAW v. OSHA, 37 F3d 605 (DC Cir 1994).

108 Amalgamated Meat Cutters v. Connally, 337 F. Supp. 737 (DDC 1971).
} 
obliged to come up with "subsidiary" principles to cabin its own discretion. This part of the Court's opinion owed its origins to some imaginative writing from Kenneth Culp Davis. ${ }^{109}$ The requirement of "subsidiary" principles seemed important to the decision, but it need not be seen as indispensable to it. It would be possible to read the relevant statute, in its context, as sharply limiting executive discretion, and thus to uphold it without relying at all on the need for a narrowing construction by the agency. ${ }^{110}$

But the basic idea was significantly extended in an important case involving the Occupational Safety and Health Act. ${ }^{111}$ The relevant provision authorized the agency to set standards "reasonably necessary or appropriate" to provide safe and healthful places of employment. ${ }^{112}$ But what does this mean? Is this an open-ended delegation of authority? Would it be sufficient to say that the statute told the agency to do no more, and no less, than was "reasonably necessary or appropriate"? The court of appeals did not think that that would be sufficient. It was concerned that the statutory terms could mean any number of things. It could mean, for example, that OSHA should engage in cost-benefit analysis; perhaps a standard is not "reasonably necessary or appropriate" unless the benefits justified the costs. Or it could mean that OSHA was supposed to regulate all "significant risks" to a maximally protective point, subject perhaps to a constraint that the regulation be "feasible" for industry. Or it could mean something else. Because of the statutory term's apparent plasticity, the court was obviously tempted to strike down the statute on nondelegation grounds. But instead of doing so, the court remanded the case to OSHA, concluding that the agency could save the statute with a narrowing construction. On remand, the agency generated what the court found-barely-to be a sufficient response. ${ }^{113}$ According to the agency, the statute required it to regulate only "significant risks," and only to the point of "feasibility," and within those constraints the agency was required to select the standard that would be most protective of workers. The court said that this was enough to satisfy the constitutional concern.

\footnotetext{
109 See Kenneth Culp Davis, A New Approach to Delegation, 36 U Chi L. Rev 713 (1969).

110 In brief: The wage and price freeze was a response to the perception that the nation was in the midst of "cost-;push" inflation. That was the statutory background. If that is what the statute was about, then the President could not play favorites, or reward his friends and punish his enemies. I say a bit more on this issue below.

${ }^{111}$ International Union, UAW v. OSHA, 928 F2d 1310 (DC Cir 1991).

11229 USC 652 (8)

${ }^{113}$ International Union, UAW v. OSHA, 37 F3d 605 (DC Cir 1994).
} 
Notwithstanding the Supreme Court's ruling in ATA, the approach of the court of appeals is not impossible to understand. If we are concerned about an absence of accountability, and also about values associated with the rule of law, a narrowing construction at the agency level can do a great deal of importance. Such a construction can expose the agency's standard to public oversight and review; it increases transparency and to that extent accountability. And by ensuring that agency action will be undertaken pursuant to a clear standard, a narrow construction can go a long way toward alleviating the concern of arbitrary, unpredictable agency action, treating the similarly situated differently. But we should be careful not to say that the purposes of the nondelegation are the doctrine itself, or to dissociate the doctrine from Article I, its legal source. At most, a narrowing construction can be helpful when the Court is otherwise in equipoise. The nondelegation concern is not eliminated by such a construction.

This is basically the Court's response in ATA. ${ }^{114}$ And it is evident that after $A T A$, the court of appeals' approach is entirely unacceptable. The Supreme Court has made clear that a narrowing interpretation by the agency cannot save an otherwise objectionable delegation. And in the end the Court's reasoning makes perfect sense. If the problem is that Congress has failed to lay down standards for agencies to follow, how can the agency's own standards resolve that problem? The question seems all the harder to answer in light of the fact that the source of the nondelegation doctrine is Article I, section 1, which vests legislature power in a "Congress of the United States." The purpose of the nondelegation doctrine, it would seem, is to require Congress to legislate. Agency narrowing is neither here nor there.

2. The line revisited - and OSHA's fate. How, then, should the now-rejected court of appeals decisions be understood? Might the Court have (inadvertently?) given a new boost to the nondelegation doctrine, by suggesting that a narrowing construction cannot be helpful? These questions are not simple to answer. The case of freezing wages and prices is the easier to handle. To be sure, Congress did not give clear standards in the text of the statute. But statutory terms receive meaning from context, and the context behind the Act suggested a desire to protect the nation from a certain kind of inflationary pressure, captured in the notion of "cost-push inflation," in accordance of which unions and employers create a kind of psychological spiral, one that needs to be broken through law. ${ }^{115}$

\footnotetext{
114 See 121 S. Ct. at 111.

115 See Stephen Breyer and Richard B. Stewart, Administrative Law and Regulatory Policy 80-83 (2d ed. 1985).
} 
The statute itself did not refer to this theory, but it is clear, from context, that Congress did not seek to give the President the authority to freeze prices and wages in a way that involved political favoritism. If the statute should be interpreted so as to avoid the constitutional difficulty, it would not be an intolerable stretch to say that any executive action should be reviewed with the particular context in mind-and hence that statutory purpose sharply limited presidential discretion. Perhaps it will be responded that Congress should be required to say all this clearly in the statutory text itself. But would much be gained by requiring this step? This is far from obvious.

But the contested provision of OSHA is much harder. The phrase "reasonably necessary or appropriate" seems, on its face, to leave everything open. To be sure, the phrase might at first appear similar to the standard that the Court found sufficient in ATA. But there is a big difference. In ATA, the Court held, immediately before upholding the statute against nondelegation attack, that the statute required a "health only" determination, and that it did not allow consideration of costs. ${ }^{116}$ The ATA Court held the statute constitutional in part because Congress was clear on this point; Congress itself decided that costs would not count, and the agency was not permitted to create the legal standard out of thin air. It seems to follow that if a statute itself requires consideration of costs, and hence a form of cost-benefit balancing, it would also be constitutional, notwithstanding the high levels of residual discretion that would remain. What makes the relevant provision of OSHA much harder is that it seems to give the agency discretion to decide whether the statute does or does not allow consideration of costs, and thus to decide what the statutory standard is. This was Chief Justice Rehnquist's objection to another provision of OSHA ${ }^{117}$-an objection that was rejected on the ground that that provision could be authoritatively construed sharply to discipline the agency's discretion. ${ }^{118}$

Nothing in $A T A$, in short, resolves the question whether a court should uphold a statute that leaves the agency the authority to constructs its most fundamental meaning. Now it is important to be careful with this point. As we have seen, lower courts have created an interpretive principle authorizing agencies to consider costs if they see fit, and ATA seems to approve of this

\footnotetext{
116121 S. Ct. at 109-110.

117 See Industrial Union Department, AFL-CIO v. API, 448 US 607, 624 (1980) (Rehnquist, J., concurring in the judgment) (objecting on nondelegation grounds to 29 USC 655 (b)(5)).

118 See id at 611 (interpreting provision in a way that implicitly rejects the nondelegation challenge); see also Whitman v. American Trucking Association, 121 S. Ct. at 911 (interpreting the Benzene Case as rejecting nondelegation challenge).
} 
principle. ${ }^{119}$ It would be implausible to suggest that a statute is unconstitutional if it allows an agency to decide whether or not to consider costs; this kind of decision has been found acceptable in many contexts, and ATA cannot be taken to say that the underlying statutes are now unconstitutional. After ATA, the appropriate answer to the constitutional question is this: Statutes that allow agencies to decide whether to consider costs admittedly confer considerable discretion. But after ATA, this is the further thing from fatal. The rest of the relevant statutes typically contains real limits on agency discretion. Even if agencies are allowed to decide whether or not to consider costs, they do not, under those statutes, have anything like a blank check.

But OSHA's "reasonably necessary or appropriate" language seems quite different on this count. In the abstract, that language allows the agency to choose the statutory standard. The significance of $A T A$ is that if this conclusion is to be avoided, it cannot be for the reason invoked by the court of appeals. It must be because the statute is best construed to cabin agency discretion to some degree. We know, for example, that the statute bars measures that are unreasonable, or inappropriate, as means of achieving safe work places. In this way the statute can be taken to require cost-effectiveness, and also to require the agency to pursue the end of worker safety. But is this enough? The end of worker safety can be pursued in multiple ways. To be sure, the constitutional doubt would be removed, under $A T A$, if the statute were construed to require cost-benefit balancing. ${ }^{120}$ We can easily imagine a judicial opinion that would so construe the statute; perhaps a step is "reasonably necessary or appropriate" if and only if it survives balancing, all things considered. But the court of appeals was probably right to say that this interpretation, while possible, is not ordained by the statutory text. And it is because the interpretation is not ordained that the court remanded the case to the EPA for an authoritative construction. The problem, after $A T A$, is that such a construction is, with respect to the nondelegation issue, neither here nor there.

In these circumstances, future courts have only three options. The first would be a version of the route taken in ATA: to point to other statutes giving agencies broad discretion (such as the "public interest, convenience, and necessity" standard of the Federal Communications Commission) and to urge

\footnotetext{
119 See below.

${ }^{120}$ I have suggested above that a cost-benefit standard by itself leaves agencies a great deal of discretion, especially in the valuation of benefits. But under $A T A$, this degree of discretion, which is in fact quite standard, cannot possibly be taken to raise a serious constitutional problem.
} 
that the disputed provision is not much different. The problem with this approach is that it would be somewhat irresponsible without some effort to show how the agency is not permitted to do whatever it chooses. The second would be to generate an interpretation of the provision that adequately cabins agency discretion. This would certainly be possible, but the strategy in ATA-merely repeating the statutory language, with the added words "no less and no more"would not be helpful. The third would be to strike down the statute on nondelegation grounds. It is ironic but true that this route may have been made more rather than less likely as a result of the Supreme Court's rejection of the approach of the court of appeals.

Should the court take this step? In general, I think that the ATA Court was entirely correct to suggest that the nondelegation doctrine deserve little place in modern constitutional law. For this reason, some combination of the first and second routes might be best: An effort to construe the statute to impose some limitations, with a recognition that a great deal of discretion is constitutionally legitimate. But if the nondelegation doctrine deserves any place at all, the "reasonably necessary or appropriate" language, in context, would not be the worst place for judicial invalidation.

\section{The Future of National Standards (with special reference to particulates and ozone)}

After ATA, a major question is how a plaintiff might be able to challenge a national standard, if costs cannot be considered and if the constitutional route is unavailable. ATA offers little guidance here. If the regulation is less stringent than is "requisite to protect the public health," with an "adequate margin of safety," it will be unlawful. If the regulation is more stringent than is requisite, it will also be unlawful. In the easy cases, the lessons are clear. A regulation will be subject to challenge if it allows significant adverse health effects, at least if the agency cannot reasonably explain that the adverse effects are insignificant. If we accept the evidence described above, it would therefore be reasonable to argue that the EPA was required, and not merely permitted, to produce a new regulation for particulates. A regulation will also be subject to challenge if significant adverse effects cannot be expected at levels that the EPA forbids. On a reasonable reading of the evidence governing ozone, the new EPA regulation is unlawful for that reason.

I will return to these issues below. There are three major possibilities, and each of them would be entirely reasonable. In the end I will urge that the 
particulates rule should probably be upheld, but that the ozone standard should probably be remanded, so that the EPA can give a better, more quantitative explanation of why it chose the particular regulatory "points" that it selected. This judgment is tentative. What is more important than the conclusion is an appreciation of the grounds on which the three possibilities might be criticized and defended.

1. A soft look. The court might say that there is substantial scientific evidence to support the view that both pollutants produce significant adverse health effects at currently permitted levels -- and hence the new controls are, in the administrator's reasonable judgment, "requisite to protect the public health." The statutory requirement of an "adequate margin of safety" might well be taken to support this view. As I have emphasized, the evidence supporting regulation of ozone seems a good deal weaker than the evidence supporting regulation of ozone, especially if we take into account the fact that ground-level ozone seems to have nontrivial health benefits. But perhaps a court should say that there is much scientific uncertainty here, and that the EPA should be allowed to resolve the doubts as it sees fit. If the court took this route, it would be following the direction established in the Lead Industries case, in which the EPA was given a great deal of room to maneuver. ${ }^{121}$

There are several advantages to this approach, especially if we consider the institutional role of the courts. A serious problem with intense judicial review of agency action is that it creates delay-and hence ensures a bias in favor of the status quo. ${ }^{122}$ It is exceptionally easy for a skillful adequate to challenge a national standard as either too high or too low. On the basis of EPA's own data, an environmental group would have had a quite plausible argument that the regulation of particulates was insufficiently stringent under the statute. In order to allow agencies room to maneuver in the face of scientific uncertainty, it would be reasonable to say that on the basis of minimally plausible evidence, courts should simply uphold the relevant decisions. It is a special virtue of this approach that the Bush Administration would be permitted to come to a different conclusion from the Clinton Administration, and vice-versa, because different judgments of value could lead to different conclusions about how to proceed in the face of ambiguous science.

\footnotetext{
${ }^{121}$ See Lead Industries Association v. EPA, 647 F.2d 1130 (DC Cir 1980).

122 See Jerry Mashaw and David Harsft, The Struggle for Auto Safety (1993).
} 
2. Evidentiary review. A second possibility, hinted at above, would be to invalidate the ozone regulation while upholding the regulation of particulates. The simple claim here would be that on the evidence given, the new particulates standard was requisite to protect the public health - but the new ozone standard was not, especially if we take into account the health benefits of ground-level ozone. ${ }^{123}$ We have seen the possibility that all things considered, the regulation would increase rather than reduce, health problems.

Even if this is overstated, Justice Breyer's opinion rightly suggests that the EPA is not supposed to remove all risks from the air, or to make the air "riskfree," and that the EPA should take account of context to compare the risk at hand to risks that people face in ordinary life. It does appear that the statistical risks from low levels of ozone are smaller than the statistical risks that people find acceptable in multiple domains. Particulates are very different on this count. Here the existing hazards do seem high, on a plausible reading of the evidence. By upholding the particulates standard, and asking the EPA to explain itself more thoroughly with respect to ozone, the court would be contributing to the development of a kind of common law of acceptable risks, of the sort that Justice Breyer seemed to be encouraging.

The approach I am suggesting-upholding the particulates standard as requisite, while invalidating the ozone standard as not requisite-would certainly be reasonable. The principal objection would be institutional; it would involve the special limitations of judicial review. The evidence shows the possibility of nontrivial health gains from the ozone regulation, and in the face of scientific uncertainty, the agency should be permitted to make whatever (reasonable) policy choices it likes. Especially in view of the risk of status quo bias, perhaps the court should refuse to invalidate a judgment like that in the ozone case, even if the judgment seems wrong.

3. Requiring a clear standard. A third possibility would be to invalidate both regulations as arbitrary or as inadequately justified, not because the risks are too low, but because EPA did not explain on what grounds it chose these particular regulations, rather than regulations that would be somewhat more strict or somewhat more lenient. This would be the administrative law analogue of what

\footnotetext{
${ }^{123}$ I am not attempting here to reach definitive conclusions about the scientific data. I am simply suggesting how a reviewing court might reasonably respond to the data that the EPA has compiled.
} 
Judge Williams took to be a constitutional requirement in $A T A .{ }^{124}$ The Supreme Court's holding that the nondelegation doctrine does not require this form of specificity says nothing about whether such specificity might be required as a matter of administrative law. If the EPA cannot explain, in concrete terms, why it chose the particular levels it chose, how can courts know that the agency's decision was not arbitrary?

In doctrinal terms, judicial invalidation on these grounds might take one of two routes. First, the court might say that it cannot know whether the particular level chosen is "requisite to protect the public health" unless it has a clear sense of why the EPA reached that conclusion. Without numbers and criteria, it is impossible to obtain any such sense. Second, the court might say that it cannot tell whether the agency's action is arbitrary or capricious, within the meaning of the Administrative Procedure Act, ${ }^{125}$ unless the EPA has given a more detailed explanation of its choice. Either of these conclusions would be relatively conventional, and neither would mark a huge departure from current law.

But there would be a genuine innovation here. Thus far, courts have not required anything like a quantitative basis for health and safety regulation. Sometimes they have required agencies to show that the costs are not grossly disproportionate to the benefits ${ }^{126}$; sometimes they have prohibited agencies from acting when it seems as if there are not benefits at all. ${ }^{127}$ But the relevant decisions have been more qualitative than quantitative, and when they have been quantitative, the overall judgment has seemed overwhelmingly clear. ${ }^{128}$ It would be a significant step from these decisions to a holding that agencies must quantify the effects of pollutants at various levels, so as to explain, in specific terms, why one level was chosen rather than another.

Would the step be worthwhile? While I cannot discuss the issue in detail, I believe that it would be, at least for the ozone rule, where the evidence of harm is relatively thin. ${ }^{129}$ Such a ruling would not impose an unacceptable informational burden on EPA. In fact EPA routinely gathers enough information to provide the necessary explanation. At the same time, such a requirement would provide a

\footnotetext{
124 See supra.

1255 USC 706.

${ }^{126}$ Corrosion Proof Fittings v. EPA, 947 F2d 1201 (5 $5^{\text {th }}$ Cir 1991).

127 See Chemical Manufacturers Assn. v. EPA, 217 F.3d 861 (DC Cir 2000).

128 See Corrosion Proof Fittings, at 1205-1211.

${ }^{129}$ For a detailed discussion, see Sunstein, supra note.
} 
useful spur to theagency, one that would also produce a higher degree of rationality andcoherence. The result would be to show when, and why, environmental groupsor industry would be able to mount a successful challenge to an ambient airquality standard.

In sum: I believe that on remand, the court should uphold the particulates standard, on the ground that on a reasonable view of the evidence, the agency had sufficient basis to conclude that that standard was "requisite to protect the public health," even without an attempt to quantify. At the same time, the court should remand the ozone rule, on the ground that the EPA has not given an adequate explanation of why that rule is "requisite." The court should encourage the EPA to be as quantitative as possible. And on remand, the EPA should take up the invitation, attempting in the process to give a clear sense, for the first time, of why it has chosen one regulatory "point" rather than another. But my principal goal has not been to urge any particular result, which will obviously turn on close engagement with the record. I have attempted instead to give a sense of the arguments that are available, post- $A T A$, and a general sense of the grounds on which one might choose among them.

\section{Conclusion}

The Court's principal rulings in ATA represented a return to normalcy - a rejection of some imaginative suggestions about how to read both the Clean Air Act and the Constitution. The Court established, quite correctly under existing law, that national standards should be set without regard to cost, and that the nondelegation doctrine has a small place in constitutional doctrine - or perhaps no place at all.

At the same time, the Court's unambitious, lawyerly opinion leaves a number of questions unresolved. There is some ambiguity in the case, but the opinion is best taken not to question, but on the contrary to endorse, the costbenefit default principles developed by lower courts. And while the Court showed no interest in the nondelegation doctrine, its rejection of the approach of the lower court now makes it impossible to invoke an agency's narrowing construction to support an otherwise objectionable delegation. For that reason, the nondelegation doctrine is not quite dead. I have attempted to show that the little life that remains in the nondelegation doctrine might well support a constitutional attack on the Occupational Safety and Health Act. 
ATA also leaves open a number of challenges to national ambient air quality standards, including the very standards at issue in the case. The principal challenges would involve the language of the relevant provision of the CAA ("requisite") and the arbitrary or capricious standard of the APA. On the basis of the evidence before the agency, it would make sense for a court to uphold the particulates standard as having been reasonably judged "requisite" while also invalidating the ozone standard as not shown to qualify as such. For the EPA itself, it would certainly make sense to move in the direction of greater quantification, in which national standards are issued only after an effort to specify the expected benefits, to compare them with the expected benefits of alternatives, and in that way to produce clear standards for choosing appropriate levels of ambient air quality. This is essentially an administrative task, not one for the courts. But it would be entirely appropriate for courts to spur regulatory agencies in this direction. Justice Breyer wrote only for himself, and his pragmatic, consequence-centered concurring opinion attracted no additional justices; but I believe that it will exert an enduring influence on the law of risk regulation. If so, the ATA decision will stand not only as a responsible resolution of the principal questions in the case, but also as a modest step toward a more sensible system of environmental protection.

Readers with comments should address them to:

Cass R. Sunstein

Karl N. Llewellyn Dist. Service Prof. of Jurisprudence

University of Chicago Law School

1111 East 60th Street

Chicago, IL 60637 USA

Phone: 773-702-9498

E-mail: csunstei@midway.uchicago.edu 


\section{Chicago Working Papers in Law and Economics}

(Second Series)

1. William M. Landes, Copyright Protection of Letters, Diaries and Other Unpublished Works: An Economic Approach (July 1991).

2. Richard A. Epstein, The Path to The T. J. Hooper: The Theory and History of Custom in the Law of Tort (August 1991).

3. Cass R. Sunstein, On Property and Constitutionalism (September 1991).

4. Richard A. Posner, Blackmail, Privacy, and Freedom of Contract (February 1992).

5. Randal C. Picker, Security Interests, Misbehavior, and Common Pools (February 1992).

6. Tomas J. Philipson \& Richard A. Posner, Optimal Regulation of AIDS (April 1992).

7. Douglas G. Baird, Revisiting Auctions in Chapter 11 (April 1992).

8. William M. Landes, Sequential versus Unitary Trials: An Economic Analysis (July 1992).

9. William M. Landes \& Richard A. Posner, The Influence of Economics on Law: A Quantitative Study (August 1992).

10. Alan O. Sykes, The Welfare Economics of Immigration Law: A Theoretical Survey With An Analysis of U.S. Policy (September 1992).

11. Douglas G. Baird, 1992 Katz Lecture: Reconstructing Contracts (November 1992).

12. Gary S. Becker, The Economic Way of Looking at Life (January 1993).

13. J. Mark Ramseyer, Credibly Committing to Efficiency Wages: Cotton Spinning Cartels in Imperial Japan (March 1993).

14. Cass R. Sunstein, Endogenous Preferences, Environmental Law (April 1993).

15. Richard A. Posner, What Do Judges and Justices Maximize? (The Same Thing Everyone Else Does) (April 1993).

16. Lucian Arye Bebchuk and Randal C. Picker, Bankruptcy Rules, Managerial Entrenchment, and Firm-Specific Human Capital (August 1993).

17. J. Mark Ramseyer, Explicit Reasons for Implicit Contracts: The Legal Logic to the Japanese Main Bank System (August 1993).

18. William M. Landes and Richard A. Posner, The Economics of Anticipatory Adjudication (September 1993).

19. Kenneth W. Dam, The Economic Underpinnings of Patent Law (September 1993).

20. Alan O. Sykes, An Introduction to Regression Analysis (October 1993).

21. Richard A. Epstein, The Ubiquity of the Benefit Principle (March 1994).

22. Randal C. Picker, An Introduction to Game Theory and the Law (June 1994).

23. William M. Landes, Counterclaims: An Economic Analysis (June 1994).

24. J. Mark Ramseyer, The Market for Children: Evidence from Early Modern Japan (August 1994).

25. Robert H. Gertner and Geoffrey P. Miller, Settlement Escrows (August 1994).

26. Kenneth W. Dam, Some Economic Considerations in the Intellectual Property Protection of Software (August 1994).

27. Cass R. Sunstein, Rules and Rulelessness, (October 1994). 
28. David Friedman, More Justice for Less Money: A Step Beyond Cimino (December 1994).

29. Daniel Shaviro, Budget Deficits and the Intergenerational Distribution of Lifetime Consumption (January 1995).

30. Douglas G. Baird, The Law and Economics of Contract Damages (February 1995).

31. Daniel Kessler, Thomas Meites, and Geoffrey P. Miller, Explaining Deviations from the Fifty Percent Rule: A Multimodal Approach to the Selection of Cases for Litigation (March 1995).

32. Geoffrey P. Miller, Das Kapital: Solvency Regulation of the American Business Enterprise (April 1995).

33. Richard Craswell, Freedom of Contract (August 1995).

34. J. Mark Ramseyer, Public Choice (November 1995).

35. Kenneth W. Dam, Intellectual Property in an Age of Software and Biotechnology (November 1995).

36. Cass R. Sunstein, Social Norms and Social Roles (January 1996).

37. J. Mark Ramseyer and Eric B. Rasmusen, Judicial Independence in Civil Law Regimes: Econometrics from Japan (January 1996).

38. Richard A. Epstein, Transaction Costs and Property Rights: Or Do Good Fences Make Good Neighbors? (March 1996).

39. Cass R. Sunstein, The Cost-Benefit State (May 1996).

40. William M. Landes and Richard A. Posner, The Economics of Legal Disputes Over the Ownership of Works of Art and Other Collectibles (July 1996).

41. John R. Lott, Jr. and David B. Mustard, Crime, Deterrence, and Right-to-Carry Concealed Handguns (August 1996).

42. Cass R. Sunstein, Health-Health Tradeoffs (September 1996).

43. G. Baird, The Hidden Virtues of Chapter 11: An Overview of the Law and Economics of Financially Distressed Firms (March 1997).

44. Richard A. Posner, Community, Wealth, and Equality (March 1997).

45. William M. Landes, The Art of Law and Economics: An Autobiographical Essay (March 1997).

46. Cass R. Sunstein, Behavioral Analysis of Law (April 1997).

47. John R. Lott, Jr. and Kermit Daniel, Term Limits and Electoral Competitiveness: Evidence from California's State Legislative Races (May 1997).

48. Randal C. Picker, Simple Games in a Complex World: A Generative Approach to the Adoption of Norms (June 1997).

49. Richard A. Epstein, Contracts Small and Contracts Large: Contract Law through the Lens of Laissez-Faire (August 1997).

50. Cass R. Sunstein, Daniel Kahneman, and David Schkade, Assessing Punitive Damages (with Notes on Cognition and Valuation in Law) (December 1997).

51. William M. Landes, Lawrence Lessig, and Michael E. Solimine, Judicial Influence: A Citation Analysis of Federal Courts of Appeals Judges (January 1998).

52. John R. Lott, Jr., A Simple Explanation for Why Campaign Expenditures are Increasing: The Government is Getting Bigger (February 1998). 
53. Richard A. Posner, Values and Consequences: An Introduction to Economic Analysis of Law (March 1998).

54. Denise DiPasquale and Edward L. Glaeser, Incentives and Social Capital: Are Homeowners Better Citizens? (April 1998).

55. Christine Jolls, Cass R. Sunstein, and Richard Thaler, A Behavioral Approach to Law and Economics (May 1998).

56. John R. Lott, Jr., Does a Helping Hand Put Others At Risk?: Affirmative Action, Police Departments, and Crime (May 1998).

57. Cass R. Sunstein and Edna Ullmann-Margalit, Second-Order Decisions (June 1998).

58. Jonathan M. Karpoff and John R. Lott, Jr., Punitive Damages: Their Determinants, Effects on Firm Value, and the Impact of Supreme Court and Congressional Attempts to Limit Awards (July 1998).

59. Kenneth W. Dam, Self-Help in the Digital Jungle (August 1998).

60. John R. Lott, Jr., How Dramatically Did Women's Suffrage Change the Size and Scope of Government? (September 1998)

61. Kevin A. Kordana and Eric A. Posner, A Positive Theory of Chapter 11 (October 1998)

62. David A. Weisbach, Line Drawing, Doctrine, and Efficiency in the Tax Law (November 1998)

63. Jack L. Goldsmith and Eric A. Posner, A Theory of Customary International Law (November 1998)

64. John R. Lott, Jr., Public Schooling, Indoctrination, and Totalitarianism (December 1998)

65. Cass R. Sunstein, Private Broadcasters and the Public Interest: Notes Toward A "Third Way" (January 1999)

66. Richard A. Posner, An Economic Approach to the Law of Evidence (February 1999)

67. Yannis Bakos, Erik Brynjolfsson, Douglas Lichtman, Shared Information Goods (February 1999)

68. Kenneth W. Dam, Intellectual Property and the Academic Enterprise (February 1999)

69. Gertrud M. Fremling and Richard A. Posner, Status Signaling and the Law, with Particular Application to Sexual Harassment (March 1999)

70. Cass R. Sunstein, Must Formalism Be Defended Empirically? (March 1999)

71. Jonathan M. Karpoff, John R. Lott, Jr., and Graeme Rankine, Environmental Violations, Legal Penalties, and Reputation Costs (March 1999)

72. Matthew D. Adler and Eric A. Posner, Rethinking Cost-Benefit Analysis (April 1999)

73. John R. Lott, Jr. and William M. Landes, Multiple Victim Public Shooting, Bombings, and Right-to-Carry Concealed Handgun Laws: Contrasting Private and Public Law Enforcement (April 1999) 
74. Lisa Bernstein, The Questionable Empirical Basis of Article 2's Incorporation Strategy: A Preliminary Study (May 1999)

75. Richard A. Epstein, Deconstructing Privacy: and Putting It Back Together Again (May 1999)

76. William M. Landes, Winning the Art Lottery: The Economic Returns to the Ganz Collection (May 1999)

77. Cass R. Sunstein, David Schkade, and Daniel Kahneman, Do People Want Optimal Deterrence? (June 1999)

78. Tomas J. Philipson and Richard A. Posner, The Long-Run Growth in Obesity as a Function of Technological Change (June 1999)

79. David A. Weisbach, Ironing Out the Flat Tax (August 1999)

80. Eric A. Posner, A Theory of Contract Law under Conditions of Radical Judicial Error (August 1999)

81. David Schkade, Cass R. Sunstein, and Daniel Kahneman, Are Juries Less Erratic than Individuals? Deliberation, Polarization, and Punitive Damages (September 1999)

82. Cass R. Sunstein, Nondelegation Canons (September 1999)

83. Richard A. Posner, The Theory and Practice of Citations Analysis, with Special Reference to Law and Economics (September 1999)

84. Randal C. Picker, Regulating Network Industries: A Look at Intel (October 1999)

85. Cass R. Sunstein, Cognition and Cost-Benefit Analysis (October 1999)

86. Douglas G. Baird and Edward R. Morrison, Optimal Timing and Legal Decisionmaking: The Case of the Liquidation Decision in Bankruptcy (October 1999)

87. Gertrud M. Fremling and Richard A. Posner, Market Signaling of Personal Characteristics (November 1999)

88. Matthew D. Adler and Eric A. Posner, Implementing Cost-Benefit Analysis When Preferences Are Distorted (November 1999)

89. Richard A. Posner, Orwell versus Huxley: Economics, Technology, Privacy, and Satire (November 1999)

90. David A. Weisbach, Should the Tax Law Require Current Accrual of Interest on Derivative Financial Instruments? (December 1999)

91. Cass R. Sunstein, The Law of Group Polarization (December 1999)

92. Eric A. Posner, Agency Models in Law and Economics (January 2000)

93. Karen Eggleston, Eric A. Posner, and Richard Zeckhauser, Simplicity and Complexity in Contracts (January 2000)

94. Douglas G. Baird and Robert K. Rasmussen, Boyd's Legacy and Blackstone's Ghost (February 2000)

95. David Schkade, Cass R. Sunstein, Daniel Kahneman, Deliberating about Dollars: The Severity Shift (February 2000)

96. Richard A. Posner and Eric B. Rasmusen, Creating and Enforcing Norms, with Special Reference to Sanctions (March 2000) 
97. Douglas Lichtman, Property Rights in Emerging Platform Technologies (April 2000)

98. Cass R. Sunstein and Edna Ullmann-Margalit, Solidarity in Consumption (May 2000)

99. David A. Weisbach, An Economic Analysis of Anti-Tax Avoidance Laws (May 2000)

100. Cass R. Sunstein, Human Behavior and the Law of Work (June 2000)

101. William M. Landes and Richard A. Posner, Harmless Error (June 2000)

102. Robert H. Frank and Cass R. Sunstein, Cost-Benefit Analysis and Relative Position (August 2000)

103. Eric A. Posner, Law and the Emotions (September 2000)

104. Cass R. Sunstein, Cost-Benefit Default Principles (October 2000)

105. Jack Goldsmith and Alan Sykes, The Dormant Commerce Clause and the Internet (November 2000)

106. Richard A. Posner, Antitrust in the New Economy (November 2000)

107. Douglas Lichtman, Scott Baker, and Kate Kraus, Strategic Disclosure in the Patent System (November 2000)

108. Jack L. Goldsmith and Eric A. Posner, Moral and Legal Rhetoric in International Relations: A Rational Choice Perspective (November 2000)

109. William Meadow and Cass R. Sunstein, Statistics, Not Experts (December 2000)

110. Saul Levmore, Conjunction and Aggregation (December 2000)

111. Saul Levmore, Puzzling Stock Options and Compensation Norms (December 2000)

112. Richard A. Epstein and Alan O. Sykes, The Assault on Managed Care: Vicarious Liability, Class Actions and the Patient's Bill of Rights (December 2000)

113. William M. Landes, Copyright, Borrowed Images and Appropriation Art: An Economic Approach (December 2000)

114. Cass R. Sunstein, Switching the Default Rule (January 2001)

115. George G. Triantis, Financial Contract Design in the World of Venture Capital (January 2001)

116. Jack Goldsmith, Statutory Foreign Affairs Preemption (February 2001)

117. Richard Hynes and Eric A. Posner, The Law and Economics of Consumer Finance (February 2001)

118. Cass R. Sunstein, Academic Fads and Fashions (with Special Reference to Law) (March 2001)

119. Eric A. Posner, Controlling Agencies with Cost-Benefit Analysis: A Positive Political Theory Perspective (April 2001)

120. Douglas G. Baird, Does Bogart Still Get Scale? Rights of Publicity in the Digital Age (April 2001)

121. Douglas G. Baird and Robert K. Rasmussen, Control Rights, Priority Rights and the Conceptual Foundations of Corporate Reorganization (April 2001)

122. David A. Weisbach, Ten Truths about Tax Shelters (May 2001) 
123. William M. Landes, What Has the Visual Arts Rights Act of 1990 Accomplished? (May 2001)

124. Cass R. Sunstein, Social and Economic Rights? Lessons from South Africa (May 2001)

125. Christopher Avery, Christine Jolls, Richard A. Posner, and Alvin E. Roth, The Market for Federal Judicial Law Clerks (June 2001)

126. Douglas G. Baird and Edward R. Morrison, Bankruptcy Decision Making (June 2001)

127. Cass R. Sunstein, Regulating Risks after ATA (June 2001) 